\title{
Governance strategy and costs: board compensation in Sweden
}

\author{
Sven-Olof Yrjö Collin ${ }^{1,2} \cdot$ Yuliya Ponomareva ${ }^{2}$. \\ Sara Ottosson ${ }^{3} \cdot$ Nina Sundberg ${ }^{4}$
}

(C) The Author(s) 2016. This article is published with open access at Springerlink.com

\begin{abstract}
Shareholders are not identical, but differ in their objectives and actions. One difference is the level of delegation of the principal functions to the board, which we suggest can be observed through the level of directors' compensation. We analyze the difference in board compensation through the concept of governance strategy and suggest two distinct categories of shareholder strategies: the company governance strategy and the financial governance strategy. These strategies create different distributions of governance costs, which we separate into principal costs and agency costs. We claim that the financial governance strategy adopts a higher level of delegation, which implies that the principal costs are assumed by the corporation and that agency costs are higher. This in turn can explain the higher compensation for the directors of the board compared to compensation under the company governance strategy. We test our hypothesis using a three-year panel of Swedish listed corporations and find that shareholders pursuing a financial governance strategy are associated with higher levels of board compensation. These findings suggest the existence of differences in governance strategies, reflected in
\end{abstract}

\footnotetext{
The authors thank Editor in Chief Roberto Di Pietra and two anonymous reviewers for valuable comments on earlier versions of the paper. We also thank our colleagues in Sweden, at Corporate Governance Research Group at Linnaeus University and Kristianstad University for providing useful insights. We greatly appreciate helpful comments we received at EURAM conference (2014) and at the Academy of Banking, Sumy, Ukraine. The project was financed by the Söderberg foundation. David Harrison at Proper English AB contributed with language editing.

Sven-Olof Yrjö Collin

Sven-Olof.Collin@hkr.se

1 Department of Business Administration and Work Science, Kristianstad University, 29188 Kristianstad, Sweden

2 School of Business and Economics, Linnaeus University, Växjö, Sweden

3 EY, Stockholm, Sweden

4 Swedish Agency for Economic and Regional Growth, Jönköping, Sweden
} 
governance costs through board compensation, among different types of shareholders in a corporation.

Keywords Board of directors - Compensation - Governance cost - Governance strategy $\cdot$ Principal cost $\cdot$ Sweden

\section{Introduction}

The assumption that shareholders are essentially the same, driven by a single objective of wealth accumulation, has had a strong influence on research in economics. The debates on separation of ownership and control, started by Smith in 1776 (1981), continuing with Marx in 1867 (1906) and Berle and Means (1932), to modern authors like Alchian and Demsetz (1972) have treated owners of the firm as a homogenous group.

Guided by the assumption of owners' homogeneity, modern research has explored the role of ownership in relation to the level of executive compensation (Cheung et al. 2005; Dyl 1988; Hambrick and Finkelstein 1995; Khan et al. 2005; Mehran 1995). It has been found that with increasing ownership concentration, which is assumed to reflect increasing monitoring capacity, the level of compensation to executives decreases (e.g. Bechmann 2008; Dyl 1988; Goldberg and Idson 1995; Mäkinen 2008; Santerre and Neun 1986; Tosi and Gómez-Mejía 1989). This standard conception implies that all shareholders follow the same dictum, have the same will and are similar in their actions, only differing in monitoring preferences and capacity depending on their ownership stake within the firm.

Several studies, however, have acknowledged shareholder diversity (Bedö and Ács 2007; Brickley et al. 1988; Connelly et al. 2010a; Cronqvist and Fahlenbrach 2009; Desender et al. 2013; Fiss and Zajac 2004; Gedajlovic et al. 2005; Hautz et al. 2013; Munari et al. 2010; Pedersen and Thomsen 2003; Thomsen and Pedersen 2000; Werner et al. 2005). Some focused on institutional investors, especially in the context of the US and the UK (Almazan et al. 2005; Connelly et al. 2010b; Cosh and Hughes 1997; Hartzell and Starks 2003; Hoskisson et al. 2002; Khan et al. 2005), also in Scandinavia (Bechmann 2008; Mäkinen 2008; Oreland 2008). Others focused on the principal-principal conflict, including the minority exploitation problem (Cronqvist and Nilsson 2003; Gaeremynck and Renders 2012; Jansson 2007; Li and Qian 2013; Nenova 2003; Young et al. 2008).

These studies used basic empirical categories, such as owner-control, ownermanaged, and management-control (Werner et al. 2005). Some suggested positional categorization distinguishing between insiders, board members, employees, blockholders, and intermediary owners such as institutions or private owners (Connelly et al. 2010b). Furthermore, Cannella et al. (2015) distinguished between a family and a lone owner while Hoskisson et al. (2002) differentiated between US institutional owners. Desender et al. (2013) differentiated Spanish and French owners dependent on their incentives and their ability to monitor.

In this paper, we develop the concept of governance strategy (Collin 2007) in order to distinguish between different types of shareholders. The concept of 
governance strategy (GS) simultaneously stresses the capacity of the principal to influence the corporation, including the ability and the will of the principal, including the incentives (Desender et al. 2013; Hoskisson et al. 2002). We use this concept in order to indicate to what extent the principal delegates principal functions. The delegation is represented by principal costs, i.e. the "cost of ownership" (Hansmann 1988), and the costs created by the delegation, the agency costs (Jensen and Meckling 1976). Based on the differences in delegation, we distinguish between two types of governance strategies: (A) company GS, characterized by large firm-specific investments by the shareholder, which, in turn, creates higher capacity to monitor and to make strategic decisions, implying low level of delegation; and (B) financial GS, which is characterized by general competence investments, and therefore with a need for greater delegation of the monitoring and decision-making functions.

We suggest that the level of delegation made by the owners through their GS can be observed through the compensation of the board of directors. The board of directors is considered to be one of the main corporate governance mechanisms assuming the functions delegated by the principal (Fama and Jensen 1983; Shleifer and Vishny 1997). As such, the board has received a lot of attention in relation to its tasks (e.g. Huse 2007), functions (e.g. Hillman and Dalziel 2003; Collin 2008), composition (e.g. Zahra and Pearce 1989) and its structure (e.g. Smith 2007). We suggest that the level of delegation made by the owners through their GS can be observed through the board, and more specifically, through directors' compensation.

However, little research has addressed the issue of board compensation (Andreas et al. 2012; Barontini and Bozzi 2011; Ryan and Wiggins 2004). In these studies, based mainly on US data, compensation has been found to vary with characteristics of the firm, such as size (e.g. Adams and Ferreira 2009), performance (e.g. Barontini and Bozzi 2011) and risk (e.g. Nguyen 2014); with board structure such as board size (Andreas et al. 2012), activity (e.g. Boyd 1996), and compensation structure (e.g. Barontini and Bozzi 2011); with board composition such as independent directors (Nguyen 2014), interlocking directors (e.g. Boivie et al. 2015), and presence of female directors (Adams and Ferreira 2009); and with corporate governance such as negative correlation with ownership concentration (e.g. Schmid 1997), ownership by directors and/or CEOs (e.g. Oxelheim and Clarkson 2015), and ownership structure, especially family (e.g. Barontini and Bozzi 2011; Schmid 1997) and institutional investors (e.g. Nguyen 2014; Cordeiro et al. 2000), the latter two factors providing mixed results.

Our study extends this research by considering the diversity of owners through the concept of GS. We claim that board compensation differs partly due to the magnitude and the distribution of principal and agency costs, which reflects the different levels and kinds of delegation performed by owners through their GS. Specifically, we predict that presence of shareholders pursuing financial GS will increase board compensation, while pursuing company GS will decrease it. By doing so we extend the conception of the owner as being beyond a mere monitoring device, considering the differences between functions delegated, which, in turn, reflect in varying principal and agency costs. 
We test our predictions on a three-year panel of Swedish listed corporations. Despite its modest size, the Stockholm Stock Exchange has high liquidity and share efficiency characteristics making it comparable with stock exchanges in other European countries, such as Germany, Ireland, Portugal, and the United Kingdom (Worthington and Higgs 2004). Sweden could be regarded as a mix of the AngloAmerican governance system of strong, liquid stock markets and the Eurasian governance system with strong stakeholders (Heidrick and Struggles 2009). Its board system is also characterized as a mixed system (Oxelheim and Clarkson 2015).

This paper continues with the theory section, where we derive our hypothesis based on the conception of GS, including the existence of variations of GS among different types of shareholders. The subsequent section describes the empirical method and presents the operationalization of variables. The results of the analyses are presented and the paper ends with conclusions.

\section{Theory}

\subsection{The governance strategy of a principal}

Let us assume that every shareholder has a will related to their shareholding that is reflected in their actions (Elston and Goldberg 2003). This will makes them more or less prone to, and capable of making decisions and taking part in the development of the firm. It also makes them more or less likely to delegate these tasks and thereby to have different capacities and interests in monitoring the delegated tasks. Simply put, shareholders may differ in their GS (Collin 2007).

GS is based on the notion that the shareholder's will is expressed in both the direction and the strength of one's interest in governance of a corporation. The GS is created through investments in information, information channels, competence, networks, and ownership. These investments create the capacity of the shareholder to form a GS, which will be implemented through influencing the bundles of firm corporate governance mechanisms (García-Castro et al. 2013). Consequently, the shareholder may have an influence on the choice and the structure of specific corporate governance mechanisms, one of which is the board of directors. Thus, the capacity of the shareholder creates the opportunities and limitations to perform their ownership functions (Alchian and Demsetz 1972), such as directing the corporation, or directing the governance of the corporation, or simply by only assuming the risk of the corporation. One implication of GS is that shareholders pursuing different GSs vary in the ways they may influence the corporation. Hoskisson et al. (2002) selected a strategy attitude by focusing on innovation strategies as an indicator of variance of shareholder preferences. We chose the governance mechanism, which is subject to the delegation of the shareholder, the board and, particularly, its compensation, to capture indications of such variation. 


\subsection{Governance costs: principal costs and agency costs}

Our conception of GS is that shareholders vary in the delegation of their tasks, implying that the cost of performing the task, as well as the cost of monitoring are differently distributed between shareholders and the corporation, depending on GS. One important aspect of delegation is the delegation of principal tasks to the board, which can be observed through the costs of the board, i.e., board compensation.

The cost distribution can be understood through making a cost distinction in agency theory. Agency costs are costs that arise because of the delegation of tasks from the principal to the agent (Jensen and Meckling 1976). The principal delegates tasks to the agent with the expectation of receiving agency revenues from the division of labor. But with the agency revenues come agency costs, which exist because the principal has reasons to believe that the delegated tasks will not be performed in perfect alignment with the principal's will. In the presence of information asymmetry, managers may pursue their own interests at the expense of shareholders' capital (Fama and Jensen 1983). The principal could accept receiving less satisfaction of the will through residual loss, or could invest in information acquisition in order to be able to influence the agent through monitoring or investing in incentives that will align the agent's interests with the will of the principal.

We suggest that shareholders differ in GS, i.e. how the shareholder will influence the corporation through the corporate governance mechanisms. Each GS has governance costs (Hansmann 1988), referring to costs that are created and distributed by the shareholder. Governance costs consist of principal costs and agency costs. Principal costs are those that belong to the functions of the principal and belong to the "costs of ownership" (Hansmann 1988), including the costs of strategy formation and strategy implementation. Principal costs can be assumed by the principal or, through the delegation of the tasks, can be assumed by the corporation, for example, through the cost of the board of directors. When a principal creates a board, with the function of implementing a strategy through a TMT, the function of strategy implementation is delegated to the board, and with it, the principal cost of implementation. However, with delegation come agency costs including the costs of monitoring. Monitoring is a function that can be performed through different tasks and carried out by the principal, or even that function can be delegated to the board. Indeed, the function of monitoring is claimed to be a major function of the board (Hillman and Dalziel 2003). Thus, the delegation of principal tasks implies that the corporation will assume the principal cost of these tasks, and the delegation creates agency costs. In sum, there are governance costs that can be separated into principal costs and agency costs, where the cost distribution is a consequence of the different GSs.

This conception makes us sensitive to what activities a shareholder could be expected to perform, i.e. what GS to pursue, since principal tasks are either performed by the shareholder or delegated, mainly to the board and the top management team (TMT). Our proposition is that more delegation of principal tasks will imply that the principal costs of competence, knowledge, and monitoring will be assumed by the corporation and reflected through the compensation of the board of directors. 


\subsection{Governance strategies tied to ownership categories}

In order to be able to test the proposition that board compensation is influenced by GS, we present two contrasting GSs that differ in the level of delegation and the distribution of governance costs. We then tie them to different empirical ownership categories in order to make the conception testable.

We distinguish between the company GS and the financial GS. Shareholders following company GS tend to absorb principal costs and therefore have lower agency costs, while shareholders following financial GS delegate principal tasks, with the effect that some principal costs are absorbed by the corporation and agency costs are created due to the delegation. We argue here that shareholders that are families, individuals or corporations tend to employ a company GS, and that institutional investors, be they domestic or foreign, employ a financial GS.

\subsubsection{Company GS}

Company GS employed by shareholders that are families, individuals and corporations is characterized by the objectives of a going concern (Fiss and Zajac 2004), growth (Randøy and Goel 2003), and, when it concerns families, socioemotional wealth (Gomez-Mejía et al. 2007). These types of shareholders invest significant amounts of resources and skills into the specific corporation (Cheng and Firth 2006). Tied to the corporation through their investments of high specificity (Williamson 1985), they have strong incentives and preferences for engagement in the corporation (Anderson and Reeb 2003), safeguarding their competence investment, since a major change of the corporate strategy would make their competence investment worthless. Close ties with the corporation make them less interested in the transferability of the shares, but with the debt arising from the need of investment in the shares of the corporation, they have a preference for dividends in order to pay for the interest on their debt.

Corporations can, however, be expected to differ slightly from individuals and families since they are expected to make investments in ownership out of pure business interest, while individuals, and, especially, families invest for the survival of the firm. Since corporations invest due to the business interest, they have firmspecific information and competence. This, in turn, creates a strong incentive to influence the owned corporation, in order to assure that its strategy is aligned with the strategy of the owner corporation. This implies a similar GS. One difference is their instrumental approach to ownership, giving corporate investors a higher preference for transferability of their shares than in the case of family owners.

It can be assumed that family, individuals, and corporate owners tend to intervene in the corporation. They may even influence the compensation system of the whole corporation, as indicated in the case of family owners (Werner et al. 2005). Thus, the expectation is that company GS implies active and specific actions by the shareholder, with business survival as an important goal and with less sensitivity to financial performance. Since they have made large firm-specific investments, they have the interest (Anderson et al. 2003) and the competence to interfere in the firm in order to influence the strategy of the firm and to monitor the 
actions performed by both the CEO and the board. They assume the principal tasks and internalize more of the principal costs. Less delegation reduces the demand on the directors to perform monitoring and decision-making functions. Reduced responsibilities and demands imply reduced levels of director pay (McConaughy 2000). Additionally, the agency costs inherent in directors' pay will be less pronounced since the company GS decreases information asymmetry between managers and shareholders.

Overall, with company GS shareholders present, we expect a lower level of delegation where directors' pay will be lower due to (1) lower costs for director competence since the principal cost is internalized by the owner and (2) lower agency costs due to limited director opportunism.

\subsubsection{Financial GS}

Financial GS is employed by institutional investors, be they domestic or foreign. Recent studies distinguish institutional investors from other owner categories (e.g. Gedajlovic et al. 2005) and investigate their influence on executive compensation (Almazan et al. 2005). Institutional investors express an emphasis on financial returns and have a strong preference for transferability of their shares since their major actions include exit and entry (Coffee 1991). To keep the exit opportunity, they do not invest strongly in firm-specific knowledge, implying lower monitoring capacity. This argument falls in line with Maug (1998) who asserts that liquid stock markets are associated with lower propensity of monitoring of larger shareholders. Furthermore, investors are required to hold a diversified portfolio (Roe 1991), which weakens their incentives to obtain industry- or firm-specific knowledge needed for the principal function of strategy formation.

Despite their inability to assume the governance function, institutional investors can compensate by strengthening other governance mechanisms, such as the compensation policy (David et al. 1998), promoting variable compensation (Almazan et al. 2005; Chung and Pruitt 1996; Firth et al. 2007; Haynes et al. 2009), and thereby being exposed to agency costs such as opportunistic timing of options (Bebchuk et al. 2010). Another action would be to delegate monitoring and decision making to the professionals at the board, thus transferring the principal cost from the shareholder to the corporation, and more specifically, to the board. With low firm-specific competence, institutional investors become more prone to influence the composition and compensation of the board of directors. They will, therefore, increase directors' compensation in order to assure effective monitoring and decision-making competence.

In the case of Sweden, due to regulation, investors cannot implement variable pay through share options for board members. Investors can, however, influence the composition of the board. Foreign investors may prefer to recruit more international directors. Due to the nature of their national culture and due to tax system differences, international directors can be expected to have higher levels of compensation, which in turn lead to further increases in the costs of the board.

The emphasis on board composition and board compensation in the financial GS is further stressed by the fact that the institutional investors have an information 
disadvantage. They are on the periphery of the Swedish business elite that has historically comprised large shareholders, represented primarily by banks, families, and some industrial corporations (Collin 1998). This isolation is even more stressed when it concerns foreign institutional investors, who are assumingly not included in the business elite, and who also partly lack the understanding of Swedish business traditions. While we lack studies supporting or refuting this speculation, distance to the elite could be assumed to reduce the opportunities to obtain privileged information, thus reducing even further the decision-making and the monitoring capacity (Masulis et al. 2012).

The financial GS has no strong preference for liquidity. While dividends could be used as a means of corporate governance, reducing the free cash flow of the corporation - subject to manager's opportunism - the main source of cash for this category of shareholders is probably not through corporate dividend, but through selling shares and receiving deposits from investors. Additionally, shareholders pursuing financial GS seldom sell shares due to need of cash, except for cases when the fund is in crisis and investors withdraw their investments. Thus, shareholders pursuing financial GS may overall sell for reasons of timing rather than for any cash needs. That reinforces their exit behavior and weakens their interest in monitoring themselves. Additionally, they have opportunities to exit when not satisfied with the actions performed by the TMT and the board, only restricted when they have substantial investments in the specific corporation (Hoskisson et al. 2002).

With a less strong monitoring capacity and a weak interest in active involvement from the institutional shareholders, directors can more easily exploit the lower monitoring capacity of shareholders through opportunism, thus increasing their compensation. Additionally, realizing that attracting foreign directors will increase the board compensation, opportunistic Swedish directors may promote recruitment of international directors. Since compensation is usually equally distributed among the board members, with the exception of higher fees for the chairperson, the higher fee for the international director(s) will influence the compensation of every director. While it can appear to be in search of a client effect, signaling the adherence to American standards in order to attract foreign investors to reduce the cost of capital (Oxelheim and Randøy 2005, 2013), the presence of international directors can also be interpreted as an indication of Swedish directors' opportunism.

Overall, we suggest that with increasing influence of shareholders pursuing financial GS, with higher level of delegation, the board compensation will increase, since (1) the principal cost is assumed by the board and (2) the agency costs increase due to director opportunism.

Considered together, we argue that the governance costs manifested through board compensation differ between the two GSs. Namely, shareholders pursuing company GS internalize principal costs and create less agency costs, thus implying lower board compensation. On the other hand, shareholders pursuing financial GS transfer principal costs to the board and create higher agency costs, implying higher board compensation. Based on this, we formulate the following hypothesis:

H1 With increasing influence of financial GS, board compensation will increase; i.e., with increasing influence of company GS, board compensation will decrease. 


\section{Method}

\subsection{Data and sample}

Our sample included Swedish corporations appearing on the Stockholm Stock Exchange from 2010 to 2012, capturing companies of all sizes, industries, and ages, thus allowing a high variation among firms. We hand-collected information on board members from 750 annual reports. In cases where information was unavailable, additional searches were made in the ORBIS database. The financial and sales data were collected from the ORBIS database. The sample included companies on which full information was obtained, comprising an unbalanced panel of 595 firm-year observations, of which 193 were from 2010, 196 from 2011 and 206 from 2012. The final sample represents $79 \%$ of the total firm-year observations in the original sample.

\subsection{Dependent variable: board compensation}

In accordance with previous studies, board compensation was calculated as the compensation of an average director serving on a board of a focal firm, i.e. total directors' fees divided by the size of the board excluding the CEO (Andreas et al. 2012). In this measurement, total directors' fees were calculated as the sum of total compensation for all board members, including committee participation fees and excluding CEO compensation. Given that board compensation was not normally distributed in our analysis, we used natural logarithm values.

\subsection{Operationalization of independent variables: company and financial GSs}

GSs were operationalized at the firm level as the relative proportion of ownership that belonged to each of the two distinct groups of shareholders. We first measured the voting rights of the five largest shareholders in each corporation under the assumption that the degree of influence of the board and consequently the board compensation is inherent in voting rights and not profit rights. Then we assigned each of the shareholders to an ownership category, coding them as family, individual, corporation, domestic, or foreign institutional shareholders. In order to fully capture ownership of individuals and families, we identified owners behind corporations linking their name to individuals or families using previous research on Swedish business groups and corporate elites (Collin 1998; Fristedt and Sundqvist 2009). The senior author was responsible for the coding, since he had extensive knowledge about the Swedish governance system. In order to reduce subjectivity, two colleagues coded a random sample of the owners $(n=73)$, resulting in interrater reliability of 0.88 and 0.84 . We identified individuals, families, and company shareholders to belong to company GS, while institutional shareholders, whether domestic or foreign, were identified as belonging to financial GS. We then summarized the voting rights that were coded to belong to one of the two GSs. To 
consider the relative influence of voting rights, we divided the ownership voting share of each GS by the sum total voting rights of the five largest owners.

\subsection{Control variables}

\subsubsection{Board committees}

There is general agreement among researchers, policymakers, and corporate governance activists that introduction of board committees increases the transparency and accountability of the board (Aguilera and Cuervo-Cazurra 2004; Zattoni and Cuomo 2008). For this reason, corporate boards have increasingly been experiencing institutional pressure to divert their work into committees (DeFond et al. 2005; Ruigrok et al. 2006; Ponomareva and Ahlberg 2015). Swedish Code of Corporate Governance recommends firms to have at least three committees: nomination, audit and remuneration committee. The nomination committee is a subcommittee of Annual General Meeting, while the latter two committees adhere to the board (Larsson-Olaison 2014). In order to maintain legitimacy, firms tend to adopt more committees (Luoma and Goodstein 1999). Having an extra committee on the board (in addition to the ones required by the code) may be a sign of conforming to institutional demands, which implies higher costs, ultimately leading to higher fees for directors. Furthermore, participation in committee meetings requires time and preparation, thus increasing the workload of directors (Brick et al. 2006), which is compensated through a higher fixed fee and additional committee fees. Also, committee work is aimed at increasing specialization of board tasks. The efficiency of the board can be assumed to increase with its specialization, thus motivating higher compensation. Due to both efficiency and legitimacy reasons we expect to find a positive relationship between the number of board committees and the level of board compensation. To capture committee work, we created a dummy variable, coding 1 if the board had more than two committees (audit and remuneration committees) and 0 otherwise.

\subsubsection{Board meetings}

The number of board meetings can constitute another force of board compensation. A larger number of meetings implies increasing workload and time commitment from the directors, thereby requiring higher compensation. We therefore expect to find a positive association between the number of board meetings and the board compensation. We measured board meetings as the number of times the board held meetings in person, via phone or by teleconference over the year.

\subsubsection{Board size}

Size of the board has been argued to influence the effectiveness and efficiency of the corporation (Mak and Li 2001). Larger and more complex corporations may require larger boards assuming a greater responsibility of directors (Linck et al. 2009). Larger boards may also attract more competent directors, resulting in an increase in 
the overall level of compensation. We thus expect larger boards to have higher compensation. To measure board size, we counted the number of directors that were elected by the annual meeting of shareholders, excluding deputy members and employee representatives. If someone arrived or retired during the year, we counted the person as present if they had been present six months or more.

\subsubsection{Female directors}

In many occupations, an increasing presence of female employees implies reduced wages (Elkinawy and Stater 2011; Muñoz-Bullón 2010). Women are expected to have weaker negotiation skills and less orientation toward high compensation as an indication of success (Stuhlmacher and Walters 1999). However, this could not be expected in our case since board compensation is not negotiated individually, and in the case of boards, probably more influenced by the dominant sex, i.e. males. Another reason for a non-significant relationship could be that females at the top of organizations have become socialized and selected to conform to the norms of the organizations, making gender aspects largely absent. Finally, due to intense publicity of female directors in Sweden over the last years, the board and the owners could be assumed to be sensitive to the need to avoid discrimination based on gender. Adams and Ferreira (2009) found a weak positive correlation between fraction of female directors and compensation. Overall, we cannot find a strong reason to make any directional expectation. We measured the proportion of female directors as the number of female directors divided by the size of the board.

\subsubsection{Independent directors}

Inclusion of independent directors on the board has been stipulated by the Swedish Code of Corporate Governance (NASDAQ OMX 2009). To be considered as independent, directors should not have any business ties or employment in respect to the company or its major shareholders. In addition, the CEO is the only insider allowed to be part of the board according to Swedish Corporate Governance Code. These requirements increase the demand for independent directors, making them a scarce resource for listed companies (Johanson and Østergren 2010). In addition, independent directors will be under higher pressure to guard their reputation, which increases their risks and can therefore require higher compensation. We therefore expect director independence to drive their individual compensation and, as a result, the overall level of board compensation. The proportion of independent directors was measured as the number of independent directors divided by the size of the board.

\subsubsection{International directors}

International directors can be expected to increase the compensation of the board members since they are attracted from societies that pay their elite higher wages (Conyon and Murphy 2000; Elston and Goldberg 2003), and because of their specific competencies (Oxelheim and Randøy 2005). There could also be a client 
effect (Dolphin 2004) where a corporation pays excess for an international director in order to appear legitimate in the eyes of foreign investors or an agency cost due to potential opportunism from domestic directors to increase their wages. We observed nationality using data from the annual reports, or when lacking information, using the ORBIS database. Due to similarity in practice and traditions of corporate governance, we considered Scandinavian directors as one category including directors with Swedish, Danish, Norwegian, and Finnish origin (Sinani et al. 2008). We included a proportion of foreign directors measured as the number of nonScandinavian directors divided by the size of the board.

\subsubsection{Board tenure}

With increasing tenure, a director can be assumed to accumulate more detailed knowledge about the corporation, its markets and environments (Taylor 1975), thus increasing in competence (Combs and Skill 2003), which could induce an increase of compensation. Tenure could also, however, be an indicator of a fortified board, with strong influence (cf. Randøy and Nielsen 2002), which would increase their compensation. Due to human experience, embeddedness and power (Gomez-Mejia and Wiseman 1997), we expect a positive relationship. On the other hand, high tenure could indicate that the directorship is relatively safe, thus motivating a lower compensation. ${ }^{1}$ We average the number of years that all directors have served on the board.

\subsubsection{Board interlocks}

Directors' personal capital, reflected in the number of the board appointments, indicates a good reputation and market demand for a particular director (Mizruchi 1996). Board interlocks also serve as an indication of social capital associated with belonging to corporate elites (Westphal and Stern 2006), showing that directors who sit on multiple boards are more likely to obtain new board appointments (Davis 1993). To attract directors with social and personal capital represented by multiple board appointments, the company may need to offer higher compensation. Additionally, by social comparison processes, interlocks can drive compensation (Boivie et al. 2015). Thus, we expect boards with larger numbers of board appointments to have higher levels of director compensation. We measured director interlocks by calculating the average number of board appointments per board.

\subsubsection{Dual shares}

In Sweden, about $46 \%$ listed corporations have a separation between profit and voting rights through dual class shares. Less financially strong shareholders, presumably with a company GS, would prefer stocks with strong voting rights, which would make us expect a negative relationship with board compensation. However, with a separation between voting and profit rights, risk of minority

\footnotetext{
$\overline{1}$ We thank an anonymous reviewer for suggesting this explanation.
} 
exploitation could enter in, which would put demands on the directors to reduce this risk. In this case, strong directors are needed, which presumably increases the compensation. Thus, we are inclusive to direction. We used a dummy variable to account for dual class shareholder ownership, assigning 1 to companies that have multiple classes of shares, and 0 to ones with common shares.

\subsubsection{Corporate performance}

Corporate performance has been used as a control variable for explaining executive compensation in previous studies (Andreas et al. 2012). If the company has been performing well, we would expect the board of directors to receive larger compensation. Firm past performance was measured using natural logarithm of return on assets lagged by 1 year (lnROA).

\subsubsection{Sales volatility}

Boards may require greater compensation based on the level of risks involved in their decision making (Andreas et al. 2012; Hahn and Lasfer 2011). Highly complex environments involve greater risks in decision making. The increased difficulty of directors' tasks associated with environmental complexity may in turn require higher board compensation (Brick et al. 2006). Firm sales volatility assumes greater uncertainty, thus such firms are perceived as being more risky (Srivastava et al. 1999). We measured standard deviation of firm sales for the last 5 years as a proxy for risks associated with the business context of a firm.

\subsubsection{Firm sales}

Firm size has been found to correlate positively with the compensation at the top levels of the corporation (Andreas et al. 2012; Conyon and Murphy 2000; Elston and Goldberg 2003; Gomez-Mejia and Wiseman 1997), which could be caused by the demand for skill and efforts. To reduce its skewedness, firm size was measured as a natural logarithm of firm sales (Sapp 2008).

\subsubsection{Year and industry}

These were included as control variables in all models. Industry was coded according to the Stockholm Stock Exchange 10-category classification based on the information collected from the exchange's website.

\subsubsection{Herfindahl index}

To compare our model of governance strategies with earlier research suggesting higher concentration reducing board compensation (Andreas et al. 2012; Goldberg and Idson 1995; Kraft and Niederprüm 1999; Oxelheim and Clarkson 2015) we created a variable measuring ownership concentration using the Herfindahl index of the five largest ownership shares, counted as voting rights. 


\section{Analysis and results}

\subsection{Summary statistics}

Inspecting Table 1, we find that the average compensation for a director in 2010-2012 was 301,259.40 Swedish Krona, approximately €32,515 or \$36,302, but with a standard deviation of similar size, thus indicating a considerably large variation. The company GS has an average of $67 \%$ of the five largest owners, while the financial GS has $33 \%$, thus indicating that owners with a company GS invest more in the control of the corporation. Inspecting the control variables, we can see that the board structure variables show that the corporations have on average 6.56 directors. The board characteristics variables show that on average boards have about $23 \%$ female directors and $8.87 \%$ international directors. Approximately half of all corporations have dual class shares. Furthermore, each director has on average 3.74 additional board appointments.

Although a correlation matrix needs to be interpreted with caution because of pooled data, the pattern of association is consistent with our predictions (see Table 2). Inspecting the two GSs, we see that company GS is associated with lower level of board compensation, lower number of board committees, lower share of international and independent directors and higher board tenure, but no correlation with female presence. This is partly in line with our conception since we argued that company GS will be closer to the corporation, thus not in need of board committees, either as a means to solve governance problems or as a legitimizing instrument.

\subsection{Model specification}

Our data consist of an unbalanced panel with three observation periods precluding us from using ordinary least squares (OLS) regression. Since OLS does not account for unobserved heterogeneity in terms of within- and between-firm effects (Afuah 2001), using this method on panel data analysis may produce correlated error terms, under estimated standard errors and inflates t-statistics (Sanders and Hambrick 2007). Our sample has a very low within-firm variability. Firstly, board and ownership characteristics are essentially time-invariant (Cannella et al. 2015). From the descriptive statistics presented in Table 1, we can notice that the means of board and ownership variables, including compensation, do not change considerably over the years. In addition, firm sales and firm performance variable also include a large time-invariant component, i.e. past performance and sales drive future performance and sales. Furthermore, our sample comprises only three years of observations, indicating that the within-unit sample is relatively small. Applying fixed-effects models to our data will disregard between-firm effects; given that board characteristics vary slowly over time, this model specification may not have enough information to explain the relationship (Adams et al. 2005; Pathan 2009). To accommodate these concerns, we decided to proceed with feasible generalized least squares (FGLS) regression, which is a version of a random-effects model. We use firm, year, and industry fixed-effects to control for time invariant characteristics. 


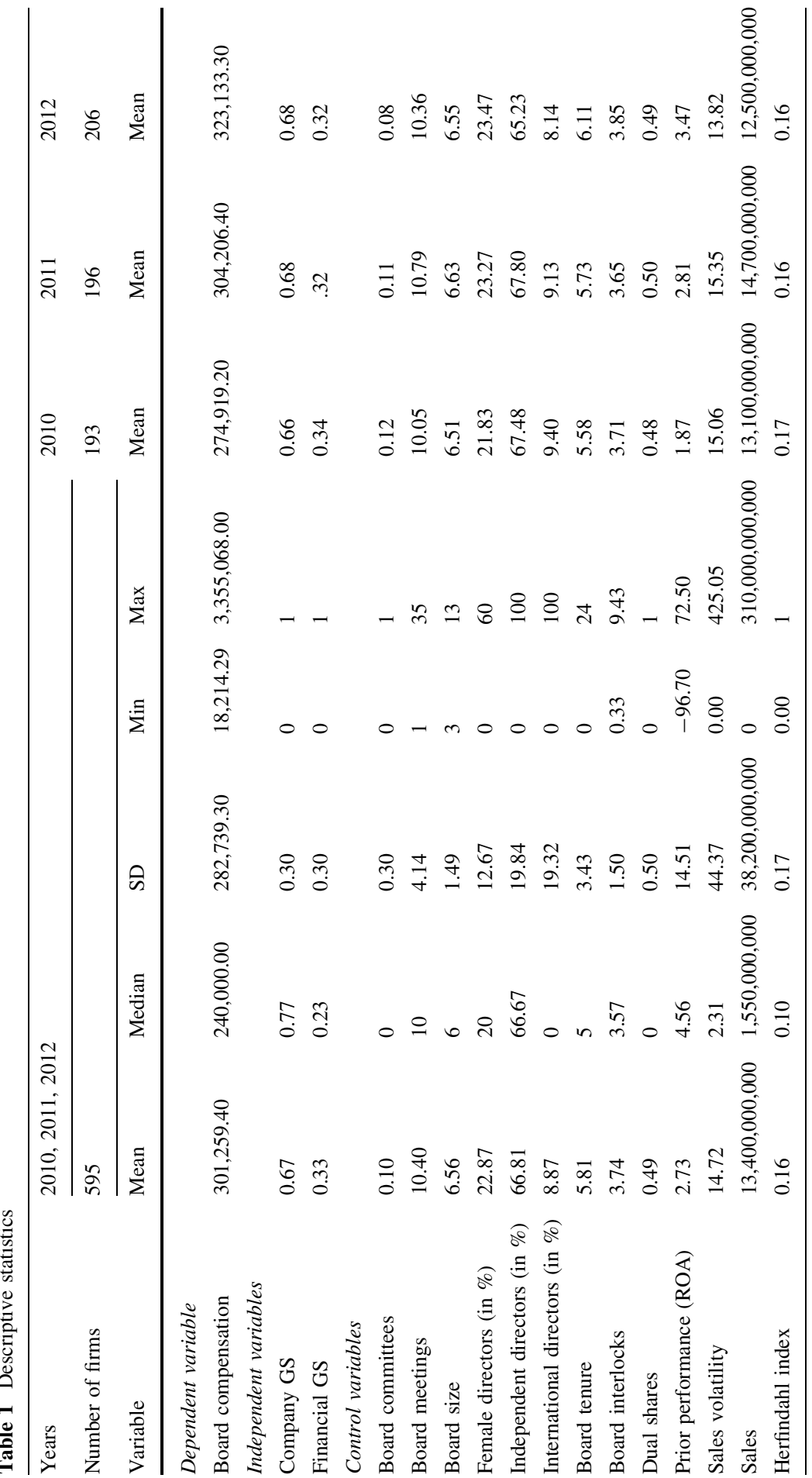




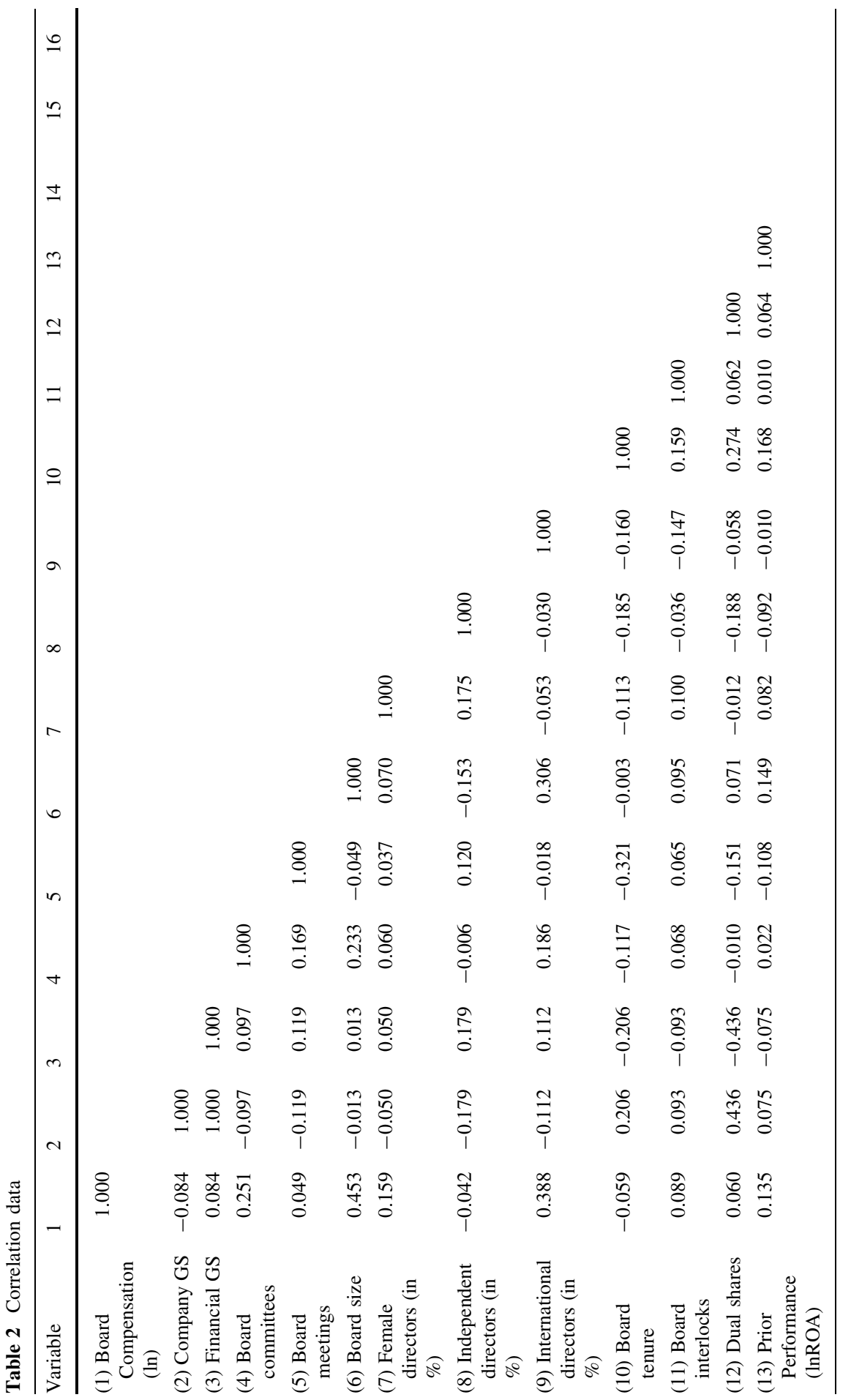




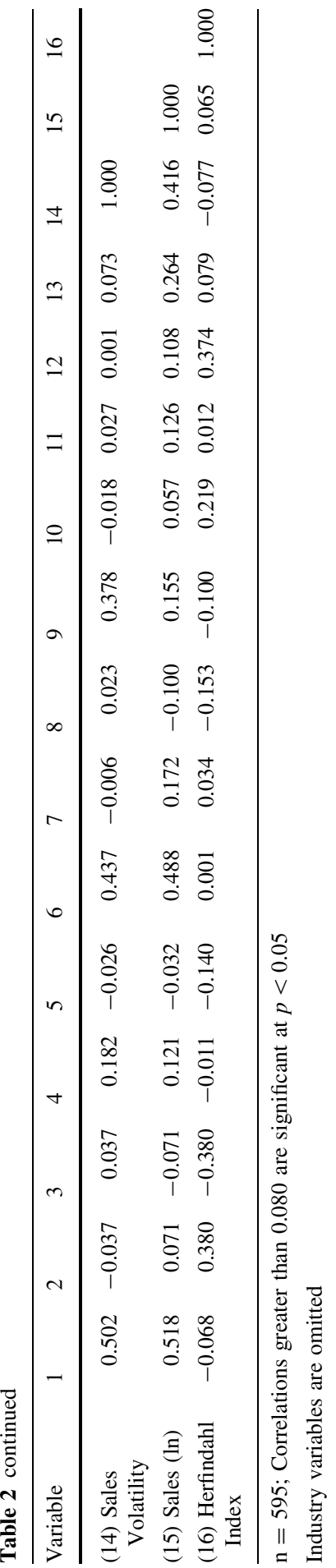


This model specification is appropriate considering the nature of our sample, as it accounts for the presence of heteroscedasticity which was found in our sample (Geletkanycz and Hambrick 1997). It has also been widely used in research in corporate governance (Cannella et al. 2015; Westphal and Zajac 1995; Zhou 2001).

\subsection{Results}

In Table 3, we present the results of our analysis. Models I and II are control models only, while Model III presents the effects of financial GS on board compensation. $\mathrm{H} 1$ predicted that with increasing presence of financial GS the level of board compensation will decrease, while with increasing presence of company GS it will decrease. Our results support this prediction (Model III). Model II also shows that ownership concentration measured as Herfindahl index negatively influences the level of board compensation $(\beta=-0.2810, p=0.032)$. The Herfindahl index does, however, hide the reality of GS: that owners differ and are influenced differently when increasing their share of ownership. Model I presents the effects of board and firm characteristics on board compensation. We show that the level of board compensation is significantly positively related to number of board committees ( $\beta=0.1927, p=0.006)$. As expected, larger boards are associated with larger board compensation $(\beta=0.0391, p=0.019)$. The presence of female directors shows significant positive effect on board compensation $(\beta=0.0057, p=0.001)$. Dual class shareholding is positively related to board compensation in Models II ( $\beta=0.0990, p=0.024)$ and III $(\beta=0.1242, p=0.006)$. Furthermore, presence of a foreign director also shows significant positive effect on the level of board compensation $(\beta=0.0074, p=0.000)$. Consistent with our predictions, firm size shows positive relationship with board compensation in models I, II and III. As $\mathrm{R}^{2}$ cannot be reliably interpreted in GLS models (Klementa 1986), we do not report these values. Wald Chi square value is significant in all four models with increasing $\chi^{2}$ as we add variables of interest to the equation. Overall, our results provide support for our hypothesis, suggesting that shareholder GSs influence the level of board compensation.

To test the sensitivity of our models, we performed several robustness checks, paying special attention to the problem of endogeneity (Shaver 1998). One potential source of endogeneity could be unobserved variables that affect both dependent and independent variables (Antonakis et al. 2010). We aimed to minimize the missing variable bias by including a comprehensive set of control variables at board, firm, and industry levels. We performed several regressions excluding and including control variables, which have shown results consistent with our final model. Another source of endogeneity could be inversed causality. Is it the GS that influences the board compensation, or have owners with a specific view of a GS been attracted to the corporation, partly due to the board compensation? Only an empirical study geared towards causality can judge this controversy. For us it is not of great importance since our theory states that shareholders pursuing financial GS prefer to transfer principal costs and those pursuing company GS absorb these costs. Whether this is performed through influencing the corporation or through investing in a corporation that has this cost structure does not influence our theory. In addition, 
Table 3 Shareholder GSs and board compensation

\begin{tabular}{|c|c|c|c|c|c|c|}
\hline \multirow[t]{2}{*}{ Independent variables } & \multirow[t]{2}{*}{ Prediction } & \multicolumn{5}{|c|}{ Dependent variable: Board compensation } \\
\hline & & (I) & (II) & (III) & (IV) & $(\mathrm{V})$ \\
\hline Board committees & + & $\begin{array}{l}0.1927 * * \\
(0.0694)\end{array}$ & $\begin{array}{l}0.1986 * * \\
(0.0692)\end{array}$ & $\begin{array}{l}0.1773 * \\
(0.0690)\end{array}$ & $\begin{array}{l}0.1718 * \\
(0.0693)\end{array}$ & \\
\hline $\begin{array}{l}\text { Board committees } \\
\text { (Alternative measure) }\end{array}$ & + & & & & & $\begin{array}{l}0.9471 * * * \\
(0.1410)\end{array}$ \\
\hline Board meetings & + & $\begin{array}{l}0.0054 \\
(0.0052)\end{array}$ & $\begin{array}{l}0.0047 \\
(0.0052)\end{array}$ & $\begin{array}{l}0.0047 \\
(0.0051)\end{array}$ & $\begin{array}{l}0.0046 \\
(0.0052)\end{array}$ & $\begin{array}{l}0.0004 \\
(0.0050)\end{array}$ \\
\hline Board size & + & $\begin{array}{l}0.0391 * \\
(0.0167)\end{array}$ & $\begin{array}{l}0.0381 * \\
(0.0166)\end{array}$ & $\begin{array}{l}0.0354 * \\
(0.0166)\end{array}$ & $\begin{array}{l}0.0349 * \\
(0.0166)\end{array}$ & $\begin{array}{l}0.0445 * * \\
(0.0160)\end{array}$ \\
\hline Female directors (in \%) & $+/ \mathrm{ns}$ & $\begin{array}{l}0.0057 * * * \\
(0.0017)\end{array}$ & $\begin{array}{l}0.0059 * * * \\
(0.0017)\end{array}$ & $\begin{array}{l}0.0054 * * * \\
(0.0017)\end{array}$ & $\begin{array}{l}0.0056 * * * \\
(0.0017)\end{array}$ & $\begin{array}{l}0.0058 * * * \\
(0.0016)\end{array}$ \\
\hline $\begin{array}{l}\text { Independent directors } \\
\text { (in \%) }\end{array}$ & + & $\begin{array}{l}-0.0003 \\
(0.0011)\end{array}$ & $\begin{array}{l}-0.0005 \\
(0.0011)\end{array}$ & $\begin{array}{l}-0.0006 \\
(0.0011)\end{array}$ & $\begin{array}{l}-0.0006 \\
(0.0011)\end{array}$ & $\begin{array}{l}-0.0008 \\
(0.0010)\end{array}$ \\
\hline $\begin{array}{l}\text { International directors } \\
\text { (in } \% \text { ) }\end{array}$ & + & $\begin{array}{l}0.0075 * * * \\
(0.0012)\end{array}$ & $\begin{array}{l}0.0074 * * * \\
(0.0012)\end{array}$ & $\begin{array}{l}0.0074 * * * \\
(0.0012)\end{array}$ & $\begin{array}{l}0.0075 * * * \\
(0.0012)\end{array}$ & $\begin{array}{l}0.0067 * * * \\
(0.0012)\end{array}$ \\
\hline Board tenure & + & $\begin{array}{l}-0.0044 \\
(0.0067)\end{array}$ & $\begin{array}{l}-0.0031 \\
(0.0067)\end{array}$ & $\begin{array}{l}-0.0039 \\
(0.0066)\end{array}$ & $\begin{array}{l}-0.0036 \\
(0.0066)\end{array}$ & $\begin{array}{l}-0.0005 \\
(0.0064)\end{array}$ \\
\hline Board interlocks & + & $\begin{array}{l}0.0178 \\
(0.0138)\end{array}$ & $\begin{array}{l}0.0166 \\
(0.0137)\end{array}$ & $\begin{array}{l}0.0205 \\
(0.0137)\end{array}$ & $\begin{array}{l}0.0207 \\
(0.0137)\end{array}$ & $\begin{array}{l}0.0149 \\
(0.0133)\end{array}$ \\
\hline Dual shares & - & $\begin{array}{l}0.0689 \\
(0.0417)\end{array}$ & $\begin{array}{l}0.0990 * \\
(0.0438)\end{array}$ & $\begin{array}{l}0.1242 * * \\
(0.0450)\end{array}$ & $\begin{array}{l}0.1198 * * \\
(0.0449)\end{array}$ & $\begin{array}{l}0.1062 * \\
(0.0437)\end{array}$ \\
\hline $\begin{array}{l}\text { Prior } \\
\text { performance (lnROA) }\end{array}$ & + & $\begin{array}{l}0.0615 \\
(0.0872)\end{array}$ & $\begin{array}{l}0.0621 \\
(0.0869)\end{array}$ & $\begin{array}{l}0.0719 \\
(0.0866)\end{array}$ & $\begin{array}{l}0.0701 \\
(0.0867)\end{array}$ & $\begin{array}{l}0.0450 \\
(0.0840)\end{array}$ \\
\hline Sales volatility & + & $\begin{array}{l}0.0037 * * * \\
(0.0005)\end{array}$ & $\begin{array}{l}0.0036 * * * \\
(0.0005)\end{array}$ & $\begin{array}{l}0.0037 * * * \\
(0.0005)\end{array}$ & $\begin{array}{l}0.0036 * * * \\
(0.0005)\end{array}$ & $\begin{array}{l}0.0041 * * * \\
(0.0005)\end{array}$ \\
\hline Sales (ln) & + & $\begin{array}{l}0.0721 * * * \\
(0.0091)\end{array}$ & $\begin{array}{l}0.0726 * * * \\
(0.0090)\end{array}$ & $\begin{array}{l}0.0737 * * * \\
(0.0090)\end{array}$ & $\begin{array}{l}0.0730 * * * \\
(0.0090)\end{array}$ & $\begin{array}{l}0.0636 * * * \\
(0.0005)\end{array}$ \\
\hline Financial GS & + & & & $\begin{array}{l}0.2341 * * \\
(0.0749)\end{array}$ & & $\begin{array}{l}0.1985 * * \\
(0.0728)\end{array}$ \\
\hline Financial GS Dominance & & & & & $\begin{array}{l}0.2558 * * \\
(0.0877)\end{array}$ & \\
\hline Herfindahl index & - & & $\begin{array}{l}-0.2810^{*} \\
(0.1309)\end{array}$ & & & \\
\hline Industry & & Included & Included & Included & Included & Included \\
\hline Year & & Included & Included & Included & Included & Included \\
\hline Constant & & $\begin{array}{l}9.8016 * * * \\
(0.4241)\end{array}$ & $\begin{array}{l}9.8421 * * * \\
(0.4229)\end{array}$ & $\begin{array}{l}9.6585 * * * \\
(0.4232)\end{array}$ & $\begin{array}{l}9.5301 * * * \\
(0.431)\end{array}$ & $\begin{array}{l}9.7880 * * * \\
(0.4102)\end{array}$ \\
\hline Wald chi-square & & $573.64 * * *$ & $582.69 * * *$ & $592.79 * * *$ & $590.34 * * *$ & $668.81 * * *$ \\
\hline
\end{tabular}


Table 3 continued

\begin{tabular}{llllll}
\hline Independent variables & Prediction & \multicolumn{5}{l}{ Dependent variable: Board compensation } \\
\cline { 2 - 6 } & (I) & (II) & (III) & (IV) & (V) \\
\hline $\mathrm{N}$ & 595 & 595 & 595 & 595 & 595 \\
\hline
\end{tabular}

Standard errors are reported in parentheses

${ }^{\dagger} p<0.10$

$* p<0.05$

$* * p<0.01$

$* * * p<0.001$

ownership structure changes very little over the years. Considering that board compensation in the Swedish context is relatively small in its significance, it becomes unlikely that ownership structure would change in response to the small changes in board compensation.

To ensure the robustness of our results we ran our model with alternative measurements of our variables. Firstly, we used the alternative measure of financial GS, calculating it as the proportion of financial GS in relation to company CG, based on the ownership of the five largest owners. This measurement captures the dominance of financial GS over company GS. The results of alternative measure of the independent variable (Table 3, Model IV) were consistent with the results of our final model. Furthermore, we employed an alternative measure of board committees, suggested by an anonymous reviewer, calculating directors' workload as the number of committees per board divided by the number of directors. This measure primarily captures directors' workload. The results of our model (Table 3, Model V) were consistent with the results of our final model.

\section{Discussion and conclusion}

This paper has addressed the issue of shareholder diversity. We have shown that board compensation in Swedish listed corporations is related to shareholders' GS. These results are in line with previous research studying how different types of shareholders influence practices of corporate governance. Croci et al. (2012) found that family ownership is associated with the reduction of CEO compensation, while the presence of institutional investors increases the level of CEO pay. Desender et al. (2013) found that owners that we would characterize as performing a company GS use the board monitoring to a lesser extent through examining the interaction of board composition and audit costs. This is in line with our findings. Interestingly, however, Desender et al. (2013) found a positive correlation between audit costs and the categories of families and corporations compared to widely held corporations. This indicates that company GS in France and Spain involves using audit as a means to enhance their capacity as owners (cf. Broberg 2013). An alternative explanation to the positive correlation could be that audit is a signal of credibility (Evans and 
Patton 1987) used in a company GS, perhaps especially directed towards minority shareholders. Irrespective of the explanation, the effect is that part of the principal cost of the company GS to create information about the corporation or to create legitimacy for the shareholder is absorbed by the corporation.

We explain these results through our conception of shareholders' GS. We propose that shareholders, depending on their prerequisites, their capacity and their goals, create different GSs, assuming different levels and kinds of delegation. The latter influence the magnitude and distribution of principal and agency costs ultimately comprising the overall governance costs. While agency theory tends to focus on monitoring of the agent and on agency cost, we stress all functions of the principal and the accompanying principal costs.

Our conception of principal costs differs from that of Goshen and Squire (2015) and Dalziel et al. (2011), who use the same term. Both studies define principal costs as a reduction of the optimal value of a firm inferred by conflicts between principals and, in the case of Goshen and Squire (2015), also including costs of mistakes made by the principals. We do not assume an optimal value of the firm. In contrast, we acknowledge the existence of multiple principals and assume that the value of the firm is relative to the different wills of the principals.

It should be noted that our conception is not normative. We do not claim that a GS is more or less effective than another. While our two GS have different distributions of principal costs and agency costs, we have not investigated the principal and agency revenues; thus we cannot find out anything about the effectiveness of the GS.

The concept of governance costs implies that effectiveness for a shareholder includes not only the performance of the firm, but also the shareholder's investments and costs. A focus on the firm's performance ignores the principal costs carried by the shareholder. Thus, in order to perform a study of effectiveness, one has to consider all costs that influence the shareholder, including principal costs internalized by the shareholder.

Furthermore, since the conception of GS includes the notion that different shareholders have different objectives, the firm has no optimal value, and that one single performance variable cannot be assumed in a performance study. We cannot ask the question, as do Chen et al. (2009), whether ownership matters and then reach a conclusion about effective owners when using only a single performance variable that is not derived from the ownership category and its GS. As has been found in family business studies, where the company GS appears to be dominant, family shareholders tend to focus on survival of the corporation in order to make it possible to transfer the corporation to the next generation (Gomez-Mejía et al. 2007), making financial risk, for example, important to manage. Thus, the development of financial leverage could be more important than, for example, Tobin's Q, as a performance variable when analyzing a corporation guided by a company GS. Indeed, as Thomsen and Pedersen found in their study of the largest European companies: "...ownership structure affects the priority attached to profit vs. growth objectives" (2000: 702).

Our study also contributes to research on board compensation. While not central to the study, our results provide additional evidence of factors determining the level 
of board compensation. We have corroborated earlier studies findings of board compensation being positively correlated to the size of the corporation, international directors and female presence, while being negatively correlated with ownership concentration. Most studies (e.g. Boyd 1996; Brick et al. 2006) do not find a correlation with performance, which is in accordance with our results. We found board size to be positively correlated, which is in accordance with Nguyen (2014), while Hempel and Fay (1994) and Adams et al. (2009) found no correlation, and Andreas et al. (2012) found a negative relationship. Interlocks have been found to increase compensation in two studies (Boivie et al. 2015; Boyd 1996) while we found the same null result as Andreas et al. (2012). This could indicate institutional differences since the significant correlations were found in the US data, while the non-significant results were found in Swedish and German samples. We found a positive relationship to our risk measurement, which differs from most studies, showing no correlation (e.g. Adams et al. 2009; Andreas et al. 2012; Brick et al. 2006). This could be due to the inability of these studies to observe the risk inherent in the compensation since it appears that many board directors receive variable compensation, where the risk component is hard to empirically estimate, while in Sweden, variable pay such as option plans are ruled out by regulation. On the other hand, our results indicate that if the Swedish regulators had the intention to rule out risk-adjusted compensation to boards by forbidding option plans for directors, they have failed. Our overall impression is that the mixed results indicate a need to develop more precise independent empirical variables, as well as hypotheses that are not only focused on monitoring, but (as our suggestion of a GS) including all board functions. Finally, since we argue that some deviations could have institutional reasons, it urges us to perform international studies, including several countries. Such studies would allow us separate institutionally specific relationships and general relationships.

Our study has several limitations. It is conducted in only one country over three years. Studies comparing several European countries have found differences that could be due to country-specific conditions (e.g. Munari et al. 2010). Our results are in contrast with Barontini and Bozzi (2011) who found a higher compensation in Italian family boards, presumably subject to company GSs, when compared to boards in widely held firms. This could indicate institutional differences between Latin and Nordic European countries, such as tax differences inducing dominant owners to use board compensation instead of dividends.

Another limitation concerns our concepts and their relationship to the empirical study. We distinguish between principal and agency costs, but we do not measure them empirically. The difference in board compensation is interpreted as a difference in governance costs, which contains both principal and agency costs.

Thirdly, we tie GS to empirical categories. Indeed, it is a simplification since we assume that behavior of GS is tied to the empirical categories of ownership types. This is to generalize at the expense of finding important differences, for example among institutional investors. Previous studies focusing on the behavior of institutional investors have indicated that institutional investors promote some performance variables, such as being more sensitive to current stock price fluctuations while overlooking the long-term value of their investments-in other 
words, acting myopically (Bushee 2001)—while others have found no correlation with firm-level risk (Deutsch et al. 2010). Ryan and Schneider (2002) offer a conceptual critique of the strong generalization of reducing all institutional investors into one distinct category. Detailing the institutional investor category was empirically performed by Hoskisson et al. (2002), finding that different investment fund managers differed in their preferences for innovation strategies. Connelly et al. (2010a), distinguished between dedicated and transient US institutional investors.

We assigned, however, the empirical ownership categories to the two GS based on conceptions of ownership types and empirical studies. The selected empirical categories (family, individual, corporation, domestic, and foreign institutional investors) differ from those appearing in studies of UK and US ownership (Connelly et al. 2010b). They have, however, been used in studies of Sweden (e.g. Jonnergård and Larsson Olaison 2010) and other countries in Europe (e.g. Cuomo et al. 2013; Hautz et al. 2013; Pedersen and Thomsen 2003) which are therefore presumably relevant in the present context.

The best action would be to not require the leap from GSs, which are focused on prerequisites and behavior, to ownership categories. The preferred empirical study would be a study where actual behavior of the shareholder is observed. That could be performed through case studies, or a study that combines survey data of selfobserved behavior and prerequisites and archival data.

The final limitation is that we do not consider, either in theory or in the empirical study, the relationship among shareholders-for example, the problematic relationship between dominant owners and minority owners, i.e. the principal-principal conflict (Cronqvist and Nilsson 2003; Jansson 2007; Nenova 2003). It is conceivable that a shareholder's GS is influenced by the ownership structure and the performed GS could be one negotiated among shareholders. For example, a financial GS could include an emphasis on dividend, since they can use it as a governance mechanism. But they could also accept it as part of a negotiation if another large owner performs a company GS, for example, through entrepreneurial ownership where a dividend is needed in order to pay the entrepreneur's interest. It is also conceivable that shareholders delegate principal functions, not to the corporation as in our conception, but between each other. We have treated GS as atomistic, only dependent on the shareholder's prerequisites, but developing the conception could imply negotiated GS.

The main policy implication, considering the European mission of integration with diversity, would be to stress that harmonization of regulations with an emphasis on integration would run the risk of ruining features of diversity that make the corporations competitive. We have noticed the existence of differences and found rational reasons for differences. But we cannot tell which one is the besteither for the shareholders or the country or the society. Before we will be able to show, through repeated, rigorous empirical studies, that one GS is superior to another, we should put our hope on competition in the market economy and support the existence of shareholders with different GSs. Our policy implication, addressed to Marx (1906), Berle and Means (1932), and Alchian and Demsetz (1972), can therefore be expressed: Vive la différence! 
Open Access This article is distributed under the terms of the Creative Commons Attribution 4.0 International License (http://creativecommons.org/licenses/by/4.0/), which permits unrestricted use, distribution, and reproduction in any medium, provided you give appropriate credit to the original author(s) and the source, provide a link to the Creative Commons license, and indicate if changes were made.

\section{References}

Adams, R., Almeida, H., \& Ferreira, D. (2005). Powerful CEOs and their impact on corporate performance. Review of Financial Studies, 18, 1403-1432.

Adams, R., \& Ferreira, D. (2009). Women in the boardroom and their impact on governance and performance. Journal Financial Economics, 94, 291-309.

Afuah, A. (2001). Dynamic boundaries of the firm: Are firms better off being vertically integrated in the face of a technological change? Academy of Management Journal, 44, 1211-1228.

Aguilera, R. V., \& Cuervo-Cazurra, A. (2004). The spread of codes of good governance worldwide: What's the trigger? Organization Studies, 25(3), 415-443.

Alchian, A. A., \& Demsetz, H. (1972). Production, information costs, and economic organization. The American Economic Review, 62(5), 777-795.

Almazan, A., Hartzell, J. C., \& Starks, L. T. (2005). Active institutional shareholders and costs of monitoring: Evidence from executive compensation. Financial Management, 34(4), 5-34.

Anderson, R. C., Mansi, S. A., \& Reeb, D. M. (2003). Founding family ownership and the agency cost of debt. Journal of Financial Economics, 68(2), 263-285.

Anderson, R. C., \& Reeb, D. M. (2003). Founding-family ownership and firm performance: Evidence from the S\&P 500. The Journal of Finance, 58(3), 1301-1328.

Andreas, J. M., Rapp, M. S., \& Wolff, M. (2012). Determinants of director compensation in two-tier systems: Evidence from German panel data. Review of Managerial Science, 6, 33-79.

Antonakis, J., Bendahan, S., Jacquart, P., \& Lalive, R. (2010). On making causal claims: A review and recommendations. The Leadership Quarterly, 21, 1086-1120.

Barontini, R., \& Bozzi, S. (2011). Board compensation and ownership structure: Empirical evidence from Italian listed companies. Journal of Management and Governance, 15, 59-89.

Bebchuk, L. A., Grinstein, Y., \& Peyer, U. (2010). Lucky CEOs and lucky directors. The Journal of Finance, 65(6), 2363-2401.

Bechmann, K. L. (2008). Compensation of executives in Denmark: Performance, corporate governance or rent extraction? In L. Oxelheim, \& C. Wihlborg (Eds.), Emerald Group Publishing Limited. International Business and Management, 5(24), 261-282.

Bedö, Z., \& Ács, B. (2007). The impact of ownership concentration, and identity on company performance in the US and in Central and Eastern Europe. Baltic Journal of Management, 2(2), $125-139$.

Berle, A. A., \& Means, G. C. (1932). The modern corporation and private property. New York: Macmillan.

Boivie, S., Bednar, M. K., \& Barker, S. B. (2015). Social comparison and reciprocity in director compensation. Journal of Management, 41(6), 1578-1603.

Boyd, B. K. (1996). Determinants of US outside director compensation. Corporate Governance, 4, 202-211.

Brick, I. E., Palmon, O., \& Wald, J. K. (2006). CEO compensation, director compensation, and firm performance: Evidence of cronyism. Journal of Corporate Finance, 12, 403-423.

Brickley, J. A., Lease, R. C., \& Smith, C. W. (1988). Ownership structure and voting on antitakeover amendments. Journal of Financial Economics, 20, 267-291.

Broberg, P. (2013). The auditor at work-a study of auditor practice in Big 4 audit firms. $\mathrm{PhD}$ Dissertation. Lund University.

Bushee, B. J. (2001). Do institutional investors prefer near-term earnings over long-run value? Contemporary Accounting Research, 18(2), 207-246.

Cannella, A. A., Jr., Jones, C. D., \& Withers, M. C. (2015). Family- versus lone-founder- controlled public corporations: Social identity theory and boards of directors. Academy of Management Journal, 58(2), 436-459. 
Chen, G., Firth, M., \& Xu, L. (2009). Does ownership control matter? Evidence from China's listed companies. Journal of Banking \& Finance, 33, 171-181.

Cheng, S., \& Firth, M. (2006). Family ownership, corporate governance, and top executive compensation. Managerial and Decision Economics, 27(7), 549-561.

Cheung, Y. L., Stouraitis, A., \& Wong, A. (2005). Ownership concentration and executive compensation in closely held firms: Evidence from Hong Kong. Journal of Empirical Finance, 12(4), 511-532.

Chung, K. H., \& Pruitt, S. W. (1996). Executive ownership, corporate value, and executive compensation: A unifying framework. Journal of Banking \& Finance, 20(7), 1135-1159.

Coffee, J. C. (1991). Liquidity versus control: The institutional investor as corporate monitor. Columbia Law Review, 91(6), 1277.

Collin, S.-O. (1998). Why are there these islands of conscious power found in the ocean of ownership? Institutional and governance hypotheses explaining the existence of business groups in Sweden. Journal of Management Studies, 35(6), 719-746.

Collin, S.-O. (2007). Governance strategy: A property right approach turning governance into action. Journal of Management and Governance, 11, 215-237.

Collin, S.-O. (2008). The boards functional emphasis-A contingency approach. Corporate Ownership \& Control, 6(2), 73-88.

Combs, J. G., \& Skill, M. S. (2003). Managerialist and human capital explanations for key executive pay premiums: A contingency perspective. Academy of Management Journal, 46, 63-73.

Connelly, B. L., Hoskisson, R. E., Tihanyi, L., \& Certo, S. T. (2010a). Ownership as a form of corporate governance. Journal of Management Studies, 47(8), 1561-1589.

Connelly, B. L., Tihanyi, L., Certo, S. T., \& Hitt, M. A. (2010b). Marching to the beat of different drummers: The influence of institutional owners on competitive actions. Academy of Management Journal, 53(4), 723-742.

Conyon, M., \& Murphy, K. J. (2000). The Prince and the pauper? CEO pay in the United States and United Kingdom. Economic Journal, 110, 640-671.

Cordeiro, J., Veliyath, R., \& Eramus, E. J. (2000). An empirical investigation of the determinants of outside director compensation. Corporate Governance, 8, 268-279.

Cosh, A., \& Hughes, A. (1997). The changing anatomy of corporate control and the market for executives in the United Kingdom. Journal of Law and Society, 24(1), 104-123.

Croci, E., Gonenc, H., \& Ozkan, N. (2012). CEO compensation, family control, and institutional investors in continental Europe. Journal of Banking \& Finance, 36, 3318-3335.

Cronqvist, H., \& Fahlenbrach, R. (2009). Large shareholders and corporate policies. The Review of Financial Studies, 22(10), 3941-3976.

Cronqvist, H., \& Nilsson, M. (2003). Agency costs of controlling minority shareholders. Journal of Financial and Quantitative Analysis, 38(4), 695-720.

Cuomo, F., Zattoni, A., \& Valentini, G. (2013). The effects of legal reforms on the ownership structure of listed companies. Industrial and Corporate Change, 22(2), 427-458.

Dalziel, T., White, R., \& Arthurs, J. D. (2011). Principal costs in initial public offerings. Journal of Management Studies, 48(6), 1346-1364.

David, P., Kochhar, R., \& Levitas, E. (1998). The effect of institutional investors on the level and mix of CEO compensation. Academy of Management Journal, 41(2), 200-208.

Davis, G. F. (1993). Who gets ahead in the market for corporate directors: The political economy of multiple board memberships. Academy of Management Best Papers Proceedings, 1993, 202-206.

DeFond, M. L., Hann, R. N., \& Hu, X. (2005). Does the market value financial expertise on audit committees of boards of directors? Journal of Accounting Research, 43, 153-193.

Desender, K. A., Aguilera, R. V., \& Crespi, R. (2013). When does ownership matter? Board characteristics and behaviour. Strategic Management Journal, 34, 823-842.

Deutsch, Y., Keil, T., \& Laamanen, T. (2010). A dual agency view of board compensation: The joint effects of outside director and CEO stock options on firm risk. Strategic Management Journal, 32, 212-227.

Dolphin, R. R. (2004). Corporate reputation-A value creating strategy. Corporate Governance, 4(3), 77-92.

Dyl, E. (1988). Corporate control and management compensation: Evidence on the agency problem. Managerial and Decision Economics, 9(1), 21-25.

Elkinawy, S., \& Stater, M. (2011). Gender differences in executive compensation: Variation with board gender composition and time. Journal of Economics and Business, 63, 23-45. 
Elston, J. A., \& Goldberg, L. G. (2003). Executive compensation and agency costs. Journal of Banking \& Finance, 27, 1391-1410.

Evans, J. H., \& Patton, J. M. (1987). Signaling and monitoring in public-sector accounting. Journal of Accounting Research, 25, 130-158.

Fama, E. F., \& Jensen, M. S. (1983). Agency problems and residual claims. Journal of Law and Economics, 26(2), 327-349.

Firth, M., Fung, P. M. Y., \& Rui, O. M. (2007). How ownership and corporate governance influence chief executive pay in China's listed firms. Journal of Business Research, 60(7), 776-785.

Fiss, P. C., \& Zajac, E. J. (2004). The diffusion of ideas over contested terrain: The (non)adoption of a shareholder value orientation among German firms. Administrative Science Quarterly, 49, 501-534.

Fristedt, D., \& Sundqvist, S. (2009). Ägarna och Makten i Sveriges Börsföretag 2009 [Owners and Power in Swedens Listed Companies 2009]. Stockholm: SIS Ägarservice.

Gaeremynck, A., \& Renders, A. (2012). Corporate governance, principal-principal agency conflicts, and firm value in European listed companies. Corporate Governance: An International Review, 20(2), 125-143.

García-Castro, R., Aguilera, R. V., \& Ariño, M. A. (2013). Bundles of firm corporate governance practices: A fuzzy set analysis. Corporate Governance: An International Review, 21(4), 390-407.

Gedajlovic, E., Yoshikawa, T., \& Hashimoto, M. (2005). Ownership structure, investment behaviour and firm performance in Japanese manufacturing industries. Organization Studies, 26(1), 7-35.

Geletkanycz, M. A., \& Hambrick, D. C. (1997). The external ties of top executives: Implications for strategic choice and performance. Administrative Science Quarterly, 42(4), 654-681.

Goldberg, L. G., \& Idson, T. L. (1995). Executive compensation and agency effects. The Financial Review, 30(2), 313-335.

Gomez-Mejía, L., Haynes, K., Núñez-Nickel, M., Jacobson, K., \& Moyano-Fuentes, J. (2007). Socioemotional wealth and business risks in family-controlled firms: Evidence from Spanish olive oil mills. Administrative Science Quarterly, 52, 106-137.

Gomez-Mejia, L. R., \& Wiseman, R. (1997). Reframing executive compensation: An assessment and outlook. Journal of Management, 23, 291-374.

Goshen, Z., \& Squire, R. (2015). Principal costs. Fordham Law Legal Studies Research Paper No. 2571739; Columbia Public Law Research Paper No. 14-462.

Hahn, P. D., \& Lasfer, M. (2011). The compensation of non-executive directors: rationale, form, and findings. Journal of Management and Governance, 15, 589-601.

Hambrick, D., \& Finkelstein, S. (1995). The effects of ownership structure on conditions at the top: The case of CEO pay raises. Strategic Management Journal, 16(3), 175-194.

Hansmann, H. (1988). Ownership of the firm. Journal of Law Economics and Organization, 4(2), 267-304.

Hartzell, J. C., \& Starks, L. T. (2003). Institutional investors and executive compensation. The Journal of Finance, 58(6), 2351-2374.

Hautz, J., Mayer, M. C. J., \& Stadler, C. (2013). Ownership identity and concentration: A study of their joint impact on corporate diversification. British Journal of Management, 24, 102-126.

Haynes, K. T., Tihanyi, L., Devers, C., \& Connelly, B. (2009). The effect of institutions on the CEOworker pay gap across countries. Chicago, IL: Academy of Management Annual Meeting.

Heidrick, \& Struggles, (2009). Corporate governance report 2009: Boards in turbulent times. London: Heidrick and Struggles International Inc.

Hempel, P., \& Fay, C. (1994). Outside director compensation and firm performance. Human Resource Management, 33, 111-133.

Hillman, A. J., \& Dalziel, T. (2003). Boards of directors and firm performance: Integrating agency and resource-dependence perspectives. Academy of Management Review, 28(3), 3838-3896.

Hoskisson, R. E., Hitt, M. A., Johnson, R. A., \& Grossman, W. (2002). Conflicting voices: The effects of institutional ownership heterogeneity and internal governance on corporate innovation strategies. Academy of Managament Journal, 45(4), 697-716.

Huse, M. (2007). Boards, governance and value creation. Cambridge: Cambridge University Press.

Jansson, A. (2007). Collective action among shareholder activists. Växjö: Växjö University Press.

Jensen, M. C., \& Meckling, W. H. (1976). Theory of the firm: Managerial behaviour, agency costs and ownership structure. Journal of Financial Economics, 3(4), 305-360.

Johanson, D., \& Østergren, K. (2010). The movement toward independent directors on boards: A Comparative analysis of Sweden and the UK. Corporate Governance: An International Review, 18(6), 527-539. 
Jonnergård, K., \& Larsson Olaison, U. (2010). Explaining transnational rules: Discourses and material conditions when implementing the Swedish corporate code of conduct. In J. Jemielniak \& P. Miklaszewicz (Eds.), Interpretation of law in the global world: From particularism to a universal approach (pp. 303-324). New York: Springer.

Khan, R., Dharwadkar, R., \& Brandes, P. (2005). Institutional ownership and CEO compensation: a longitudinal examination. Journal of Business Research, 58(8), 1078-1088.

Klementa, J. (1986). Elements of econometrics. New York: Macmillan.

Kraft, K., \& Niederprüm, A. (1999). Determinants of management compensation with risk-averse agents and dispersed ownership of the firm. Journal of Economic Behaviour and Organization, 40(1), $17-27$.

Larsson-Olaison, U. (2014). Convergence of national corporate governance systems: Localizing and fitting the transplants. Doctoral Thesis No190/2014. Växjö, Sweden: Linnaeus University Press.

Li, J., \& Qian, C. (2013). Principal-principal conflicts under weak institutions: A study of corporate takeovers in China. Strategic Management Journal, 34, 498-508.

Linck, J. S., Netter, J. M., \& Yang, T. (2009). The effects and unintended consequences of the SarbanesOxley Act on the supply and demand for directors. Review of Financial Studies, 22, 3287-3328.

Luoma, P., \& Goodstein, J. (1999). Stakeholders and corporate boards: Institutional influences on board composition and structure. Academy of Management Journal, 42, 553-563.

Mak, Y. T., \& Li, Y. (2001). Determinants of corporate ownership and board structure: Evidence from Singapore. Journal of Corporate Finance, 7, 235-256.

Mäkinen, M. (2008). CEO compensation, firm size and firm performance: Evidence from Finland. In L. Oxelhaim \& C. Wihlborg (Eds.), Markets and compensation for executives in Europe (pp. 283-314). Bingley: Emerald Group Publ.

Marx, K. (1906). Capital: A critique of political economy. New York: Modern Library.

Masulis, R. W., Wang, C., \& Xie, F. (2012). Globalizing the boardroom-The effects of foreign directors on corporate governance and firm performance. Journal of Accounting and Economics, 53(3), $527-554$.

Maug, E. (1998). Large shareholders as monitors: Is there a trade-off between liquidity and control? Journal of Finance, 53(1), 65-98.

McConaughy, D. L. (2000). Family CEOs vs. nonfamily CEOs in the family-controlled firm: An examination of the level and sensitivity of pay to performance. Family Business Review, 13(2), $121-131$.

Mehran, H. (1995). Executive compensation structure, ownership, and firm performance. Journal of Financial Economics, 38(2), 163-184.

Mizruchi, M. S. (1996). What do interlocks do? An analysis, critique, and assessment of research on interlocking directories. In J. Hagan \& K. Cook (Eds.), Annual review of sociology, 22 (pp. 271-298). Palo Alto, CA: Annual Reviews.

Munari, F., Oriani, R., \& Sobrero, M. (2010). The effects of owner identity and external governance systems on R\&D investments: A study of Western European firms. Research Policy, 39, 1093-1104.

Muñoz-Bullón, F. (2010). Gender-compensation differences among high-level executives in the United States. Industrial Relations, 49(3), 346-369.

Nenova, T. (2003). The value of corporate voting rights and control: A cross-country analysis. Journal of Financial Economics, 68(3), 325-351.

Nguyen, N. Q. (2014). On the compensation and activity of corporate boards. Journal of Corporate Finance, 29, 1-19.

Oreland, C. (2008). CEO cash compensation and ownership structure: The effect of family control on the pay-performance relation in Sweden. In L. Oxelhaim \& C. Wihlborg (Eds.), Markets and compensation for executives in Europe (pp. 315-348). Bingley: Emerald Group Publ.

Oxelheim, L., \& Clarkson, K. (2015). Cronyism and the determinants of chairman compensation. Journal of Business Ethics, 131(1), 69-87.

Oxelheim, L., \& Randøy, T. (2005). The Anglo-American financial influence on CEO compensation in non-Anglo-American firms. Journal of International Business Studies, 36, 470-483.

Oxelheim, L., \& Randøy, T. (2013). Globalization of monitoring practices: The case of American influences on the dismissal risk of European CEOs. Journal of Economics and Business, 70, 3-15.

Pathan, S. (2009). Strong boards, CEO power and bank risk-taking. Journal of Banking \& Finance, 33, $1340-1350$.

Pedersen, T., \& Thomsen, S. (2003). Ownership structure and value of the largest European firms: The importance of owner identity. Journal of Management and Governance, 7, 27-55. 
Ponomareva, Y., \& Ahlberg, J. (2015). Bad governance of family firms: The adoption of good governance on the boards of directors in family firms. Ephemera: Theory \& Politics in Organization, 16(1), 53-77.

Randøy, T., \& Goel, S. (2003). Ownership structure, founder leadership, and performance in Norwegian SMEs: Implications for financing entrepreneurial opportunities. Journal of Business Venturing, 18(5), 619-637.

Randøy, T., \& Nielsen, J. (2002). Company performance, corporate governance and CEO compensation in Norway and Sweden. Journal of Management and Governance, 6(1), 57-81.

Roe, M. J. (1991). A political theory of American corporate finance. Columbia Law Review, 91(1), 10-67.

Ruigrok, W., Peck, S., Tacheva, S., Greve, P., \& Hu, Y. (2006). The determinants and effects of board nomination committees. Journal of Management and Governance, 10, 119-148.

Ryan, L. V., \& Schneider, M. (2002). The antecedents of institutional investor activism. Academy of Management Review, 27(4), 554-573.

Ryan, H., \& Wiggins, R. (2004). Who is in whose pocket? Director compensation, board independence, and barriers to effective monitoring. Journal of Financial Economics, 73, 497-524.

Sanders, G. W. M., \& Hambrick, D. C. (2007). Swinging for the fences: The effects of CEO stock options on company risk taking and performance. Academy of Management Journal, 50(5), 1055-1078.

Santerre, R. E., \& Neun, S. P. (1986). Stock dispersion and executive compensation. The Review of Economics and Statistics, 88, 685-687.

Sapp, S. G. (2008). The impact of corporate governance on executive compensation. European Financial Management, 14(4), 710-746.

Schmid, F. A. (1997). Vorstandsbezüge, Aufsichtsratsvergütung und Aktionärsstruktur. Zeitschrift für Betriebswirtschaft, 67, 67-83.

Shaver, J. (1998). Accounting for endogeneity when assessing strategy performance: Does entry mode choice affect FDI survival? Management Science, 44, 571-585.

Shleifer, A., \& Vishny, R. W. A. (1997). A survey of corporate governance. The Journal of Finance, 52(2), 737-783.

Sinani, E., Stafsudd, A., Thomsen, S., Edling, C., \& Randøy, T. (2008). Corporate governance in Scandinavia: Comparing networks and formal institutions. European Management Review, 5(1), 27-40.

Smith, A. (1981). An inquiry into the nature and causes of the wealth of nations. Indianapolis: Liberty Press.

Smith, E. (2007). Gender influence on firm-level entrepreneurship through the power structure of boards. Women in Management Review, 22(3), 168-186.

Srivastava, R., Shervani, T., \& Fahey, L. (1999). Marketing, business processes, and shareholder value: An organizationally embedded view of marketing activities and the discipline of marketing. Journal of Marketing, 63, 168-180.

Stuhlmacher, A. F., \& Walters, A. E. (1999). Gender differences in negotiation outcome: A meta=analysis. Personnel Psychology, 52, 653-677.

Taylor, R. N. (1975). Age and experience as determinants of managerial information processing and decision-making performance. Academy of Management Journal, 18(1), 74-81.

Thomsen, S., \& Pedersen, T. (2000). Ownership structure and economic performance in the largest European companies. Strategic Management Journal, 21(6), 689-705.

Tosi, H. L., \& Gómez-Mejía, L. R. (1989). The decoupling of CEO pay and performance: An agency theory perspective. Administrative Science Quarterly, 34, 169-189.

Werner, S., Tosi, H. L., \& Gomez-Mejia, L. (2005). Organizational governance and employee pay: How ownership structure affects the firm's compensation. Strategic Management Journal, 26, 377-384.

Westphal, J. D., \& Stern, I. (2006). The other pathway to the boardroom: Interpersonal influence behavior as a substitute for elite credentials and majority status in obtaining board appointments. Administrative Science Quarterly, 51(2), 169-204.

Westphal, J., \& Zajac, E. J. (1995). Who shall govern? CEO/board power, demographic similarity, and new director selection. Administrative Science Quarterly, 40, 60-83.

Williamson, O. E. (1985). The economic institutions of capitalism. New York: The Free Press.

Worthington, A. C., \& Higgs, H. (2004). Random walks and the market efficiency in European equity markets. Global Journal of Finance and Economics, 1(1), 59-78.

Young, M. N., Peng, M. W., Ahlstrom, D., Bruton, G. D., \& Jiang, Y. (2008). Corporate governance in emerging economies: A review of the principal-principal perspective. Journal of Management Studies, 45(1), 196-220. 
Zahra, S. A., \& Pearce, J. A. (1989). Boards of directors and corporate financial performance: A review and integrative model. Journal of Management, 15, 291-334.

Zattoni, A., \& Cuomo, F. (2008). Why adopt codes of good governance? A comparison of institutional and efficiency perspectives. Corporate Governance: An International Review, 16(1), 1-15.

Zhou, X. (2001). Understanding the determinants of managerial ownership and the link between ownership and performance: Comment. Journal of Financial Economics, 62, 559-571.

Sven-Olof Yrjö Collin is Professor of Corporate Governance at Kristianstad University and part-time Professor of Corporate governance and Accounting at Linnaeus University, Sweden. He has published in the areas of corporate governance, accounting, auditing, public management, gender, business ethics and methodology. His current research interests focus on corporate governance, especially in family firms and auditing.

Yuliya Ponomareva has a Ph.D. in business administration and is a lecturer at the School of Business and Economics, Linnaeus University, Sweden. Her research interests include top management teams and boards of directors with focus on decision-making and corporate governance.

Sara Ottosson has a Master of Science in Business and Economics from Linnaeus University and is currently working as an Audit assistant at EY.

Nina Sundberg has a Master of Science in Business and Economics from Linnaeus University and is currently working as an Economist at Swedish Agency for Economic and Regional Growth. 